\title{
Improving Learning Outcomes and Science Process Skills Through the Project Based Learning (PJBL) Model Class IV SDN 2 Suroyudan
}

\section{Ika Ovita}

SD Negeri 2 Suroyudan

ovie.zigma@gmail.com

\section{Article History}

received 3/12/2020

revised $17 / 12 / 2020$

accepted $31 / 12 / 2020$

\begin{abstract}
This study aims to improve learning outcomes and science process skills on the Always Saving Energy Theme through the Project Based Learning (PJBL) learning model in class IV Semester 1 SD Negeri 2 Suroyudan. The subjects in this study were fourth grade students of SD Negeri 2 Suroyudan, totaling 32 students. This research is a Classroom Action Research conducted in two cycles in each cycle consisting of two meetings. Each cycle includes planning, implementing actions, observing and reflecting. The research data were analyzed using quantitative data analysis. To obtain data on students' science process skills, they used observation sheets and science process skills questionnaires, while to obtain data on learning outcomes in this study, the evaluation sheets were given in each cycle. Based on the results of the study, students' science process skills in cycle 1 were 34\%, increased to $94 \%$ in cycle 2. student learning completeness in cycle 1 was $75 \%$ with an average class of 80 increased to $100 \%$ with a class average of 92.81 in cycle 2 . From these results, it can be concluded that through the application of learning with the Project Based Learning (PJBL) model can improve learning outcomes and science process skills on the Always Saving Energy Theme in class IV Semester 1 SD Negeri 2 Suroyudan in 2019/2020.
\end{abstract}

Keywords: science process skills, learning outcomes, project based learning

\begin{abstract}
Abstrak
Penelitian ini bertujuan untuk meningkatkan hasil belajar dan keterampilan proses sains pada Pada Tema Selalu Berhemat Energi melalui model pembelajaran Project Based Learnig (PJBL) di kelas IV Semester 1 SD Negeri 2 Suroyudan. Subjek dalam penelitian ini adalah siswa kelas IV SD Negeri 2 Suroyudan yang berjumlah 32 siswa. Penelitian ini merupakan Penelitian Tindakan Kelas yang dilaksanakan dalam dua siklus pada setiap siklusnya terdiri dari dua kali pertemuan. Setiap siklus meliputi perencanaan, pelaksanaan tindakan, observasi dan refleksi. Data hasil penelitian dianalisis dengan menggunakan analisis data kuantitatif. Untuk memperoleh data keterampilan proses sains siswa yaitu dengan menggunakan lembar observasi dan angket keterampilan proses sains, sedangkan untuk memperoleh data hasil belajar dalam penelitian ini menggunakan lembar evaluasi yang diberikan pada setiap siklus. Berdasarkan hasil penelitian diperoleh keterampilan proses sains siswa pada siklus $134 \%$, meningkat menjadi $94 \%$ pada siklus 2. ketuntasan belajar siswa pada siklus $175 \%$ dengan rata-rata kelas sebesar 80 meningkat menjadi $100 \%$ dengan rata-rata kelas 92,81 pada siklus 2. Dari hasil tersebut dapat disimpulkan bahwa melalui penerapan pembelajaran dengan model Project Based Learning (PJBL) dapat meningkatkan hasil belajar dan keterampilan proses sains pada Tema Selalu Berhemat Energi di kelas IV Semester 1 SD Negeri 2 Suroyudan tahun 2019/2020.
\end{abstract}

Kata kunci: keterampilan proses sains, hasil belajar, project based learning

Social, Humanities, and Education Studies (SHEs): Conference Series https://jurnal.uns.ac.id/shes

p-ISSN 2620-9284 e-ISSN 2620-9292 


\section{PENDAHULUAN}

Permendikbud No. 65 Tahun 2013 tentang Standar Proses Pendidikan Dasar dan Menengah menginginkan proses pembelajaran yang dipandu dengan kaidahkaidah pendekatan saintifik/ilmiah. Pendekatan saintifik merupakan salah satu ciri khas yang dianggap menjadi kekuatan Kurikulum 2013 yang saat ini marak disosialisasikan pengimplementasiannya di berbagai daerah di Indonesia. Pertanyaan yang muncul selanjutnya adalah metode, model, pendekatan dan strategi apakah yang dirasa paling cocok untuk melaksanakan pembelajaran, sehingga tujuan pembelajaran dalam kurikulum 2013 dapat tercapai? Apakah guru-guru sudah benar-benar memahami metode, model, pendekatan dan strategi pembelajaran yang nantinya akan diterapkan dalam pembelajaran dan apakah para guru melaksanakan langkah-langkah pembelajaran dengan baik? Banyak strategi, model, dan metode belajar yang mendorong siswa untuk melaksanakan kaidah-kaidah ilmiah seperti yang diharapkan pemerintah melalui Permendikbud No. 65 Tahun 2013 tentang Standar Proses Pendidikan Dasar dan Menengah, diantaranya: Inkuiri, discovery, learning cycle, problem based learning, project based learning, dan sebagainya, atau yang sering kita dengarkan dalam pembelajaran sains adalah keterampilan proses sains.

Usman Samatowa (2006: 137) mengemukakan bahwa keterampilan proses sains merupakan keterampilan intelektual yang dimiliki dan digunakan oleh para ilmuwan dalam meneliti fenomena alam. Keterampilan proses sains yang digunakan oleh para ilmuwan tersebut dapat dipelajari oleh siswa dalam bentuk yang lebih sederhana sesuai dengan tahap perkembangan anak. Adapun Nuryani dan Andrian (Ali Nugraha, 2005: 125) mendefinisikan keterampilan proses sains adalah semua keterampilan yang diperlukan untuk memperoleh, mengembangkan dan menerapkan konsep-konsep, prinsip-prinsip, hukum-hukum dan teori-teori sains, baik berupa keterampilan mental, keterampilan fisik (manual) maupun keterampilan sosial.

Project Based Learning atau pembelajaran berdasarkan proyek merupakan tugas-tugas kompleks yang didasarkan pada pertanyaan-pertanyaan yang menantang atau permasalahan yang melibatkan para siswa di dalam desain, pemecahan masalah, pengambilan keputusan, atau aktivitas investigasi, memberi peluang para siswa untuk bekerja secara otonomi dengan periode waktu yang lama dan akhirnya menghasilkan produk-produk yang nyata. Thomas (dalam Wena, 2011). Selanjutnya Project Based Learning merupakan pembelajaran yang dirancang untuk digunakan pada permasalahan kompleks yang diperlukan siswa dalam melakukan investigasi dan memahaminya. Project Based Learning adalah pembelajaran dengan menggunakan proyek sebagai metode pembelajaran. Para siswa bekerja secara nyata, seolah-olah ada di dunia nyata yang dapat menghasilkan produk secara realistis (Mahanal, 2009).

Berdasarkan pendapat di atas, model pembelajaran Project Based Learning dilakukan dengan pemberian tugas-tugas berdasarkan permasalahan kompleks yang diberikan pada siswa untuk melakukan investigasi permasalahan secara berkelompok. Memberikan kesempatan siswa lebih aktif belajar karena siswa didorong aktif dalam proses bertanya, menginvestigasi, menjelaskan, dan berinteraksi dengan permasalahan. Selanjutnya siswa diminta menghasilkan sebuah produk dari hasil investigasi dan dipresentasikan.

Berdasarkan hasil analisis pada lembar observasi dan angket yang dilakukan oleh peneliti menunjukkan bahwa, ada sebuah permasalahan pada pembelajaran muatan pelajaran IPA di Kelas IV SD Negeri 2 Suroyudan. Permasalahan pembelajaran tersebut berkaitan dengan hasil belajar dan keterampilan proses sains siswa yang berpengaruh terhadap rendahnya ketuntasan belajar serta nilai siswa. Dari data hasil belajar yang diperolah peneliti pada tindakan pra siklus diperoleh bahwa dari 32 siswa hanya 18 siswa atau $56 \%$ yang telah tuntas belajar pada muatan pelajaran IPA, serta nilai rata-rata kelas baru mencapai 74.38 , sedangkan KKM yang ditentukan adalah 75. Berdasarkan permasalahan tersebut maka peneliti mencari 
solusi untuk melaksanakan sebuah Penelitian Tindakan Kelas melalui penerapan model pembelajaran Project Based Learning (PjBL) pada kelas IV semester 1 SD Negeri 2 Suroyudan. Penelitian ini bertujuan untuk meningkatkan hasil belajar dan keterampilan proses sains pada muatan pelajaran IPA tema selalu berhemat energi.

Peneliti memilih model pembelajaran Project Based Learning (PjBL) karena pendekatan pembelajaran ini memberikan kebebasan kepada peserta didik untuk merencanakan aktivitas belajar, melaksanakan proyek secara kolaboratif, dan pada akhirnya menghasilkan produk kerja yang dapat dipresentasikan kepada orang lain.

Kelebihan Model Project Based Learning antara lain: 1) Meningkatkan motivasi, dimana siswa tekun dan berusaha keras dalam mencapai proyek dan merasa bahwa belajar dalam proyek lebih menyenangkan dari pada komponen kurikulum lain, 2) Meningkatkan kemampuan pemecahan masalah, dari berbagai sumber yang mendeskripsikan lingkungan belajar berbasis proyek membuat siswa menjadi lebih aktif dan berhasil memecahkan problem kompleks. 3) Meningkatkan kolaborasi, pentingnya kerja kelompok dalam proyek memerlukan peserta didik untuk mengembangkan dan mempraktikan keterampilan komunikasi. 4) Meningkatkan keterampilan mengelola sumber, bila diimpelementasikan secara baik maka peserta didik akan belajar dan praktik dalam mengorganisasi proyek, membuat alokasi waktu dan sumber-sumber lain seperti perlengkapan untuk menyelesaikan tugas. 5) Meningkatkan ketrampilan peserta didik dalam mengelola sumber belajar. 6) Mendorong peserta didik untuk mengembangkan dan mempraktikan keterampilan komunikasi. 7) Menyediakan pengalaman belajar yang melibatkan peserta didik kompleks dan dirancang untuk berkembang sesuai dunia nyata. 8) Membuat suasana belajar menjadi menyenangkan, sehingga peserta didik maupun pendidik menikmati proses pembelajaran.

\section{METODE}

Penelitian ini adalah penelitian tindakan kelas dengan menerapkan model pembelajaran Project Based Learning (PjBL). Penelitian tindakan kelas ini terdiri dari empat tahapan dasar yaitu perencanaan (planning), pelaksanaan (acting), pengamatan (observing) dan refleksi (reflecting). Analisis penelitian ini adalah analisis deskriptif kuantitafif kualitatif dimana dalam penelitian ini selain penyajian hasil berupa data maupun angka peneliti juga menentukan bagaimana cara pengolahan hasil penelitian yakni dengan membuat analisisnya dengan menerapkan model penelitian Project Based Learning (PjBL). Penelitian ini dilaksanakan pada peserta didik kelas IV SD Negeri 2 Suroyudan Tahun Pelajaran 2019/2020 yang berjumlah 32 siswa, yaitu terdiri dari 18 siswa perempuan dan 14 siswa laki-laki dengan karakteristik siswa dan kemampuan kompetensi yang bervariasi dan dilaksanakan dalam 2 siklus. Pertemuan $\mathrm{Ke}-1 \mathrm{Hari} /$ Tanggal : Senin, tanggal 7 Oktober 2019 pada kompetensi dasar, 3.5 Mengidentifikasi berbagai sumber energi, perubahan bentuk energi, dan sumber energi alternatif (angin, air, matahari, panas bumi, bahan bakar organik, dan nuklir) dalam kehidupan sehari-hari. Pertemuan Ke - 2 Hari/Tanggal : Rabu, tanggal 9 Oktober 2019 pada kompetensi dasar, 3.5 Mengidentifikasi berbagai sumber energi, perubahan bentuk energi, dan sumber energi alternatif (angin, air, matahari, panas bumi, bahan bakar organik, dan nuklir) dalam kehidupan sehari-hari. Teknik pengumpulan data yang dilakukan dengan observasi dan tes,.

\section{HASIL DAN PEMBAHASAN}

Pada pengamatan pra siklus, hasil pengamatan keterampilan proses sains siswa dengan kategori tinggi ada 7 siswa atau 22\%, kategori sedang 9 siswa atau 28\%, dan dan kategori rendah 16 siswa atau $50 \%$, rerata skor 16 pada pra siklus dan termasuk dalam kategori rendah. Hasil pengamatan pada siklus 1 diperoleh data pada keterampilan proses sains kategori tinggi 11 siswa atau 34\% dari 32 siswa, kategori sedang 15 siswa atau 47\% dan kategori rendah 6 siswa atau 19\%. Rerata skor pada 
siklus 1 adalah 21 dan termasuk dalam kategori sedang. Pada pengamatan siklus 2 diperoleh data bahwa keterampilan proses sains dengan kategori tinggi 30 siswa atau $94 \%$ dari 32 siswa, kategori sedang 2 siswa atau $6 \%$, dan kategori rendah 0 siswa atau sudah tidak ada sama sekali .Rerata keterampilan proses sains mencapai 26 sehingga masuk dalam kategori tinggi.

Perbandingan hasil penelitian pra siklus, siklus 1 dan siklus 2 setelah dilakukan pengamatan pada saat proses pembelajaran diperoleh data sebagai berikut:

Tabel 1. Perbandingan Keterampilan Proses Sains Pra Siklus, Siklus 1 dan Siklus 2

\begin{tabular}{lcccccc}
\hline \multicolumn{1}{c}{ Hasil } & \multicolumn{2}{c}{ PRA SIKLUS } & \multicolumn{2}{c}{ SIKLUS 1 } & \multicolumn{2}{c}{ SIKLUS 2 } \\
Analisis & F & $\%$ & F & $\%$ & F & $\%$ \\
\hline Tinggi & 7 & $22 \%$ & 11 & $34 \%$ & 30 & $94 \%$ \\
Sedang & 9 & $28 \%$ & 15 & $47 \%$ & 2 & $6 \%$ \\
Rendah & 16 & $50 \%$ & 6 & $19 \%$ & 0 & $0 \%$ \\
Jumlah & 32 & $100 \%$ & 32 & $100 \%$ & 32 & $100 \%$ \\
Rata- & \multicolumn{2}{c}{16} & \multicolumn{2}{c}{20} & \multicolumn{2}{c}{26} \\
\hline
\end{tabular}

Hasil belajar pada muatan pelajaran IPA yang diukur melalui soal tes menunjukkan hasil pada pra siklus rerata 74,38 dan ketuntasan baru mencapai $56 \%$. Setelah dilakukan pembelajaran dengan menggunakan model Project Based Learning $(P j B L)$ terlihat adanya peningkatan. Pada siklus 1 rerata 78,58 dan ketuntasan $75 \%$. Dari hasil refleksi hasil tersebut masih belum mencapai indikator keberhasilan. Dengan memperbaiki kekurangan yang ada pada siklus 1 maka diperoleh hasil pada siklus 2 rerata menjadi 92,81 dan ketuntasan mencapai $100 \%$.

Tabel 2. Perbandingan Hasil Belajar Siswa Pra Siklus, Siklus 1 dan Siklus 2

\begin{tabular}{llccc}
\hline No & Hasil belajar & Pra Siklus & Siklus 1 & Siklus 2 \\
\hline 1 & Nilai Tertinggi & 95 & 100 & 100 \\
2 & Nilai Terendah & 60 & 65 & 74 \\
3 & Nilai Rata-Rata & 74,38 & 78,59 & 92,81 \\
4 & Tuntas Belajar & $56 \%$ & $75 \%$ & $100 \%$ \\
5 & Frekuensi & 17 & 24 & 32 \\
6 & Belum Tuntas Belajar & $44 \%$ & $25 \%$ & $0 \%$ \\
7 & Frekuensi & 14 & 8 & 0 \\
\hline
\end{tabular}

Tabel hasil analisis data di atas menunjukkan kenaikan hasil dan keterampilan proses sains siswa, maka dapat diperoleh hasil penelitian bahwa penerapan model pembelajaran Project Based Learning (PjBL) dapat meningkatkan keterampilan proses sains siswa dari $22 \%$ menjadi $94 \%$, serta dapat meningkatkan hasil belajar dari ratarata 74,38 menjadi 912,81 dan ketuntasan belajar dari $56 \%$ menjadi $100 \%$.

\section{SIMPULAN}

Penerapan model pembelajaran Project Based Learning (PjBL) dapat meningkatkan hasil belajar pada tema selalu berhemat energi pada siswa kelas IV Semester 1 SD Negeri 2 Suroyudan Tahun 2019/2020, dari pra siklus 74,38 meningkat menjadi 92,81 pada akhir siklus 2, Penerapan model pembelajaran Project Based Learning (PjBL) dapat meningkatkan keterampilan proses sains pada tema selalu berhemat energi pada siswa kelas IV Semester 1 SD Negeri 2 Suroyudan Tahun 2019/2020 dari pra siklus 22\% meningkat menjadi 94\% pada akhir siklus 2. 
Penerapan model pembelajaran Project Based Learning (PjBL), sangat sesuai dengan karakteristik muatan mata pelajaran IPA tema selalu berhemat energi, karena model pembelajaran Project Based Learning (PjBL) memiliki keunggulan yaitu, Meningkatkan motivasi, dimana siswa tekun dan berusaha keras dalam mencapai proyek dan merasa bahwa belajar dalam proyek lebih menyenangkan dari pada komponen kurikulum lain., Meningkatkan kemampuan pemecahan masalah, dari berbagai sumber yang mendeskripsikan lingkungan belajar berbasis proyek membuat siswa menjadi lebih aktif dan berhasil memecahkan problem kompleks, Meningkatkan kolaborasi, pentingnya kerja kelompok dalam proyek memerlukan peserta didik untuk mengembangkan dan mempraktikan keterampilan komunikasi.

Pada penerapan model pembelajaran Project Based Learning (PjBL) guru dapat menambahkan media pembelajaran yang menarik bagi siswa. Ketika guru memberikan penguatan materi, diharapkan agar materi pokok dapat diserap secara optimal oleh siswa supaya dalam melaksanakan presentasi siswa dapat memberikan penjelasan bagi dengan baik dan lengkap, Hasil penelitian ini dapat digunakan sebagai salah satu referensi untuk penelitian lebih lanjut. Model pembelajaran Project Based Learning (PjBL) diharapkan dapat memberikan referensi untuk guru dalam memilih model pembelajaran yang inovatif.

\section{DAFTAR PUSTAKA}

Ali, Nugraha. (2015). Pengembangan Pembelajaran Sains Pada Anak Usia Dini. Bandung: JILSI Foundation.

Anjarsari, Afianti Dyah. (2016). Penerapan Model Project Based Learning untuk Meningkatkan Hasil Belajar IPA Materi Struktur Tumbuhan pada Siswa Kelas IV SDN 2 Bulucangkring Jekulo Kudus. Program Studi Pendidikan Guru Sekolah Dasar Fakultas Keguruan dan Ilmu Pendidikan Universitas Muria Kudus.

Anurrahman. (2013). Belajar dan Pembelajaran. Bandung: Alfabeta.

Bundu, Patta. (2006). Penilaian Keterampilan Proses dan Sikap IImiah dalam Pembelajaran Sains. Jakarta : Depdiknas.

Donna M. Wolfinger. (1994). Science and Mathematics In Early Childhood. Education. New York: Harper Collins College Publisher.

Indri Anugraheni dkk (2017). Peningkatan Kreatifitas dan Hasil Belajar Siswa melalui Model Pembelajaran Project based Learning pada Siswa Sekolah Dasar. Program Studi Pendidikan Guru Sekolah Dasar Fakultas Keguruan dan ILmu Pendidikan Universitas Kristen Satya Wacana Salatiga.

Sudjana, Nana, (2009). Dasar-dasar Proses Belajar Mengajar. Bandung: Sinar Baru Algensindo.

Sugiyono, (2010). Metode Penelitian Pendidikan Pendekatan Kuantitatif, Kualitatif dan $R \& D$. Bandung : Alfabeta. 